\title{
Dekonstruksi Estetika dan Makna Musik Gamat di Sawahlunto, Sumatera Barat
}

\author{
Murniati $^{1}$ \\ Jurusan Musik, Fakultas Seni Pertunjukan, Institut Seni Indonesia Padangpanjang
}

\begin{abstract}
ABSTRAK
Keberagaman budaya masyarakat lokal terlihat dari kekayaan ekspresi seni budaya masyarakat, di antaranya terdapat pada musik gamat. Tulisan ini melihat dekonstruksi estetika dan makna dari fenomena perubahan bentuk dan struktur sajian musik gamat di masyarakat. Untuk membahasnya digunakan teori dekonstruksi dan estetika dengan metode kualitatif. Dekonstruksi estetika musik gamat merupakan bentuk baru dari unsur tradisi dan modern, terdiri atas struktur yang saling terkait dan membentuk sebuah sistem. Berdasarkan bentuknya, struktur ketradisian musik gamat mengalami percampuran pada idiom instrumen, tangga nada, struktur permainan dan peran musisi, struktur lagu-lagu, serta konteks dan waktu pertunjukan. Berdasarkan penelitian disimpulkan bahwa estetika keberagaman terwujud dari rasa saling menerima antarbudaya yang berbeda dalam pertunjukan musik gamat. Dekonstruksi estetika musik gamat mengandung makna makna pembauran, kreativitas dan ekspresi serta estetika multikultural.
\end{abstract}

Kata kunci: musik gamat, dekonstruksi, estetika, multikultural

\begin{abstract}
Deconstruction of Aesthetics and Meaning of Gamat Music in Sawahlunto, West Sumatra. The variety of local social culture can be seen in the richness of cultural artistic expression, among others is in Gamat music. This study deconstructs the aesthetics and meaning of the phenomena of the changes in form and structure toward the presentation of Gamat music in that society. For this purpose the deconstructional and aesthetic theory are used with qualitative method. The deconstruction of the aesthetics of Gamat music represents a new form from the traditional and modern element. It consists of interrelated structure and forms a system. Seen from its form, the structure of the tradition of Gamat music undergoes the mixture of instrumental idiom, the scale, the structure of performance and the role of musicians, the structure of the pieces as well as the context and time of performance. From the research results, it may be concluded that the aesthetics of diversity is formed from the sense of mutual acceptance towards different cultures in the performance of Gamat music. The deconstruction of the aesthetics of Gamat music embodies the meanings of social integration, creativity and expresssion, and multicultural aesthetics as well.
\end{abstract}

Keywords: gamat music, deconstruction, aesthetics, multicultural

\section{Pendahuluan}

Dekontruksi adalah sebuah istilah yang digunakan untuk menjelaskan hal baru dalam filsafat, strategi intelektual atau model pemahaman yang telah dikembangkan oleh Jaques Derrida, dan popularitasnya terkenal dengan teori dekonstruksi. Muzir (dalam Noris, 2003: 5) mengatakan,

"dekontruksi sebagai sebuah tindakan dari subyek yang membongkar sebuah obyek yang tersusun dari berbagai unsur.“.... Tugas dekonstruksi adalah.... membongkar (deconstruire)

Alamat korespondensi: Jurusan Seni Musik, ISI Padangpanjang, Jalan Bahder Johan no.35 Padangpanjang 27128. E-mail: murniisi15@gmail.com; HP: 085263712048 
struktur-struktur metafisis dan retoris yang bermain dalam teks, bukannya untuk menolak atau menyingkirkan struktur-struktur tersebut melainkan untuk menginskripsikannya kembali dengan cara lain".

Derrida menjelaskan bahwa pencarian makna teks budaya bukan secara logosentrisme (mengutamakan penafsiran tunggal). Namun bentuk, fungsi, makna budaya lebih dari satu, walaupun makna tersebut harus didekonstruksi untuk memunculkan makna baru dari peristiwa difference yang ada. Dampak poitif dekonstruksi adalah adanya upaya menghancurkan batas-batas antara konsep dan metafor tersebut, yang selama ini dipertahankan oleh strukturalis antara kebenaran dan opsisi biner (Lubis, 2004: 121). Untuk itu Derrida mengatakan makna memiliki potensi tanpa batas untuk terus mengalami perubahan (Barker, 2005: 105). Menanggapi hal itu Ritzer (2003:209) menyatakan bahwa apa yang dikatakan Derida tidak akan ditemukan masa depan pada masa lampau, tetapi masa depan tersebut adalah suatu yang diciptakan, ditemukan dan sesuatu yang belum selesai, di samping belum diketahui.

Proses dekonstruksi memahami pemaknaan tanda tidak sesederhana menemukan makna. Pemaknaan terhadap suatu hal yang dimaknai adalah suatu proses dengan cara membongkar (to dismantle) dan menganalisis secara kritis (critical analisis) hal yang dimaknai. Hubungan penanda (signifier) dan petanda (signified) tidak bersifat tetap, melainkan dalam kenyataannya dapat bersifat ditunda untuk memperoleh hubungan yang lain atau baru. Apa yang terjadi dalam proses differance penundaan ini, untuk menemukan makna lain atau makna baru itulah proses dekonstruksi. Proses dekonstruksi dalam memahami pemaknaan tanda tersebut dapat dilihat melalui estetika kesenian.

Menurut Sedyawati (2006: 124), kesenian merupakan salah satu unsur kebudayaan, sedangkan estetika termasuk di dalamnya sebagai subunsur. Estetika urusannya dengan hal keindahan dan pengalaman keindahan. Ada semacam rangsangan atau getar-getar keindahan yang pas dan selaras ketika orang berhadapan dengan suatu wujud seni. Sumardjo (2000: 58) menyebutnya sebagai emosi estetis, yaitu suatu perasaan spesifik dan khas yang dimiliki seseorang ketika berhadapan dengan suatu karya seni. Sehubungan dengan itu, sebagai sebuah pertunjukan tampilannya tentu memiliki nilai estetis yang dapat dikaji melalui sudut pandang subjektif dan objektif. Sudut pandang subjektif terpusat pada sisi orang yang melihat atau menikmatinya, sedangkan sudut pandang objektif menempatkan sisi objek atau barang yang dilihat (Soedarso. Sp, 1990: 36)

Pada zaman yang sedang serba berubah, pandangan estetika tidak hanya mengkaji segala sesuatu yang indah, cantik dan gaya, karena terdapat kecendrungan karya-karya seni zaman modern tidak lagi menawarkan kecantikan dan keindahan seperti zaman romantik maupun klasik tetapi lebih pada makna dan aksi mental (Sachari, 2002: 3). Sehubungan hal ini, Dharsono (2007:11) mengatakan bahwa sekurangnya ada tiga tingkatan basis aktivitas estetik/artistic. Pertama, pengamatan terhadap kualitas materil, warna, suara, gerak sikap, dan banyak lagi yang lainnya sesuai dengan jenis seni serta reaksi fisik. Kedua, penyusunan dan pengorganisasian hasil pengamatan yang mewujudkan konfigurasi struktur bentuk-bentuk yang menyenangkan dengan mempertimbangkan aspek unity, harmoni, kontras, balance yang selaras atau merupakan kesatuan yang utuh. Ketiga, pengamatan yang dihubungkan dengan perasaan atau emosi, yakni merupakan hasil interaksi antara persepsi memori dengan persepsi visual, hal ini terkait dengan kepekaan penghayat.

Perubahan pandangan estetika dalam kesenian dapat dilihat di daerah rantau wilayah Minangkabau. Sebagai daerah rantau, terdapat berbagai jenis kesenian anak nagari dan keberadaannya dalam masyarakat diakui sebagai bentuk permainan atau kesenian anak nagari. Kondisi masing-masing kesenian tersebut sangat bervariasi, di antaranya ada yang hidup berkembang dan berdampingan dengan komunitasnya, ada pula yang telah berubah sesuai dengan globalisasi massa dan efisiensi pendukungnya. Salah satu jenis kesenian tersebut adalah musik gamat, yaitu seni pembacaan pantun yang diiringi biola, akordion dan gendang. Isi pantun biasanya menceritakan nasib suka duka kehidupan. Secara tradisi, musik gamat merupakan ciri khas/karakter tersendiri 
dan keberadaannya hampir berlaku sama dengan musik gamat yang telah mentradisi di wilayah Minangkabau pada umumnya dan secara khusus terkait dengan masyarakat setempat dimana kesenian itu berkembang.

Dengan demikian, musik gamat sebagai bagian dari budaya (hasil ciptaan) adalah gabungan vokal dan instrumen yang merupakan jenis musik rakyat yang telah mentradisi, merupakan warisan seni/ budaya masa lampau, sekaligus musik hiburan masyarakat yang berkembang dalam masyarakat Minangkabau di berbagai daerah di Sumatera Barat termasuk Sawahlunto. Namun saat ini, musik gamat dalam masyarakat Sawahlunto mengalami perubahan dengan ketradisianya. Terdapat kemungkinan adanya percampuran unsur budaya, yang membuat musik tersebut terhimpun dalam komunitas yang beragam. Eksistensi seni pertunjukan gamat secara estetis pun tentu mengandung makna tersendiri pada perubahan seni pertunjukan.

\section{Dekonstruksi Estetika Musik Gamat}

Pertunjukan musik gamat ditampilkan dengan modifikasi-modifikasi berupa sajian instrumen dan vokal yaitu pada acara-acara hiburan masyarakat sesuai dengan situasi perkembangan musik, tuntutan hiburan kekinian, dan pengaruh musik campursari (unsur budaya Jawa modern) yang berkembang dalam masyarakat Minangkabau. Gagasan pertunjukan berupa penggabungan secara manual intrumen tradisi dan instrumen musik elektronik, serta seperangkat sound system (properti) untuk mendukung pertunjukan dan juga busana yang digunakan, khususnya pada musik gamat memadukan unsur musik tradisi dan modern.

Realitas tersebut menunjukkan orientasi nilai yang dipengaruhi oleh perkembangan zaman, seperti masuknya orgen tunggal atau keyboard. Di Sawahlunto penggunaan elektronik (teknologi) dilakukan oleh Adjoem selaku pimpinan musik campursari dalam seni pertunjukan musik gamat. Bercampurnya berbagai etnik secara tidak langsung juga mengakibatkan terjadinya percampuran kebudayaan, yang pada akhirnya unsur kebuyaan yang dianggap paling unggul akan menggeser unsur kebudayaan yang dianggap lemah. Barker (2005: 133) mengungkapkannya sebagai berikut.

"banyak orang berpandangan bahwa kita sedang mengalami sebuah periode perubahan radikal dalam tatanan sosial kita. Peta-peta tua yang dulu kita andalkan kini tak lagi memadai dihadapan ketidak pastian sebuah kekacauan global. Perubahan multidimensional dan saling terkait ini meliputi bidang ekonomi, teknologi, politik, kebudayaan dan identitas".

Dengan gambaran fenomena-fenomena tersebut, terlihat adanya kekhasan pertunjukan musik gamat di Sawahlunto. Pergeseran memunculkan bentuk baru berkaitan dengan keindahan-keindahan seni itu sendiri. Perpaduan unsur budaya pada musik gamat menunjukkan identitas lingkungan masyarakat yang multietnis dan multikultur. Oleh karena itu musik gamat di Sawahlunto merupakan jenis musik yang amat unik dan menarik untuk dipertunjukkan sebagai hiburan masyarakat dan sangat menarik perhatian (antusias) masyarakat untuk menonton. Dalam musik gamat di Sawahlunto, pelaku seni dan sajiannya menyatu dalam kelompok musik campursari.

Sebagaimana dikemukakan M. D. Nur (2000: 78) tentang perubahan yang dianggap sebagai azas transkulturasi yaitu elemen-elemen pada suatu ketika dianggap istimewa oleh suku bangsa, kini menjadi bagian dari proses kreativitas senimanseniman supranasional. Gambaran seperti ini terkait dengan keberadaan bentuk seni pertunjukan gamat di Sawahlunto yang sekarang mengalami proses perubahan. Perubahan itu tidak hanya pada bentuk sajian, namun juga estetika musik gamat dan berbagai perubahan pada beberapa aspek, baik bentuk, fungsi dan makna di masyarakat. Konsep ini dihubungkan dengan musik gamat di Sawahlunto yang memiliki elemen yang sangat kompleks, mencakup hal-hal; (1) dekonstruksi hetrogenitas etnis dalam musik gamat, (2) struktur sajian, (3) estetika musik gamat, (4) konteks dan waktu pertunjukan, (5) pentas dan panggung, serta (6) busana dan tata rias.

Hal yang menarik lagi pada musik gamat yakni dalam penyajian lagu-lagu juga nampak bervariasi seperti; lagu yang bernuansa Batak, Jawa, Minangkabau. Hal ini memberikan ciri 
multikultur pada aspek seni disajikan. Gambaran di atas secara nyata diekspresikan pada sajian musik gamat. Karakteristik musik gamat yang multikultur di antaranya; musik gamat tradisional, musik Jawa, musik Batak, musik modern. Keterpaduan antara unsur-unsur itulah membentuk musik gamat kekinian yang penyajiannya berbeda dengan musik gamat tradisional.

Dari landasan pemikiran di atas, jelas bahwa untuk melihat sebuah karya seni (musik) kapan dan dimanapun keberadaannya tidak akan terlepas dari aspek bentuk dan strukturnya. Struktur sajian dan teknik penyajian seni pertunjukan musik gamat menarik karena memiliki keterkaitan antar struktur yang terdapat di dalamnya. Musik gamat merupakan penggabungan musik vokal dan instrumental sekaligus merupakan satu kesatuan yang saling terkait. Semula musik gamat berfungsi sebagai pembawa melodi pokok teks-teks pantun Minangkabau dan instrumen berfungsi sebagai pendukung penyajian melodi pokok teks pantun berupa ritmis dan melodis secara tradisi. Namun kondisi musik gamat sekarang tidaklah seperti musik gamat yang ditampilkan sebelumnya, baik dari instrumen, struktur maupun lagu-lagu yang dinyanyikan.

Beberapa instrumen yang digunakan dalam pertunjukan gamat saat ini merupakan perpaduan instrumen yang terdiri dari unsur musik tradisi Minangkabau yaitu gandang, unsur musik Jawa: Saron (tangga nada dimodifikasi), musik keroncong (biola, cuk, ketipung, tamburin), unsur musik modern: keyboard, gitar elektrik (melodi dan bass), biola/violin, drumset. Sebagaimana yang dijelaskan Hendry (2011: 92) bahwa sistem nada yang dipergunakan pada musik gamelan Jawa adalah sistem nada pelog dan slendro. Bambang Yudoyono menjelaskan bahwa instrumen saron berlaras pelog terdiri dari tujuh wilahan nada-nada yaitu; bem (1), gulu (2), dada (3), pelog (4), lima (5), nem (6) serta barang, sedangkan saron berlaraskan slendro terdiri dari enam wilahan nada yaitu; barang (1), gulu (2), dada (3), lima (5) dan nem (6). Namun untuk kebutuhan kelompok musik gamat, alat musik dan tangga nada tersebut dimodifikasi dan dibuat dalam rakitan berdasarkan tangga nada diatonis yaitu tangga nada yang mempunyai jarak satu nada dan setengah nada (do-re-mi-fa-sol-la-si-do). Kemudian selain itu dilengkapi dengan seperangkat sound system (properti) untuk mendukung pertunjukan pentas yang terdiri; silver crest dua buah yang berfungsi untuk kontrol power gitar melodi dan keyboard, 1 buah power bass AKAI, 2 buah power amplifier tape SL 8000 dan CE 2000. Kemudian micser (16 canel) tipe MX-162 D, beserta 10 buah loud speaker. Sementara instrumen alat musik Batak tidak digunakan, namun hanya berupa teks lagu-lagu yang dinyanyikan. Kesemuanya juga tergabung dalam struktur jenis instrumen melodis, ritmis dan harmonis dengan nada-nadanya diatonis yang telah merombak musik gamat pada struktur instrumen tatanan baru. Di satu sisi bahwa pengalaman musisi itulah yang melatari perwujudan musik gamat yang sekarang, dan beragamnya komunitas pelaku seni di masyarakat sehingga memungkinkan adanya tatanan baru pada sisi lain.

Pada sajian musik gamat dari instrumen yang mengalami perubahan, secara tidak langsung realitas struktur pemain dan peran musisi juga mengalami perubahan (pembongkaran) sebagai perwujudan realitas representasi musik gamat dalam bentuk baru, sebagaimana diungkapkan Marlinus (2013), salah seorang seniman pelaku:

"sekarang musik gamat dimainkan dengan
menggunakan instrumen saron yang
berfungsi sebagai pembawa harmoni sekaligus
mewujudkan balancs, kemudian dilengkapi
oleh instrumen keyboard sebagai pengganti
peran musisi cardion dan juga menggunakan
instrumen keroncong seperti cuk. Sementara
nuansa melodiacordion sebagai ciri khas musik
gamat diperankan musisi gitar (elektrik) dan
keyboard bahkan kesannya telah didominasi
dengan instrumen elektronik ataupun
instrumen modern ditengah arus perkembangan
jaman sekarang".

Representasi musik gamat yang berubah dari ketradisiannya memberikan warna baru musik gamat. Adapun lagu-lagu yang dimainkan pada seni pertunjukan musik gamat terdiri lagu-lagu yang bervariasi, tidak saja membawakan lagu-lagu tradisi gamat yang telah terstruktur dalam sajiannya, tapi juga sudah diwarnai nuansa beraneka ragam budaya 
etnis. Kemet dan Z. Aripin sebagai musisi gamat tradisi mengatakan,

"musik gamat secara tradisi dinyanyikan dengan jenis irama lak-olai (mengayun) dan hanya mengalunkan lagu-lagu pantun Minangkabau, yang dibuka dengan lagu tempo cepat kaparinyo kemudian lagu dengan tempo lambat sampaya babayan dan selalu mempertahankan tempo secara bergantian (lagu dengan pecahannya). Namun sejak pemakaian keyboard, telah menggunakan beberapa jenis irama chaca, rumba, salsa dan sebagainya dan struktur sajian lagu pun telah memasukkan lagu-lagu dari nuansa jawa, batak".

Ungkapan tersebut menunjukkan bahwa variasi dalam penyajian lagu-lagu, memberikan corak dan nuansa baru pada musik gamat. Lagu-lagu yang dibawakan pada struktur sajian musik gamat terdiri dari; lagu-lagu tradisi gamat Minangkabau seperti, kaparinyo, anak lutuang, ramo-ramo, talang suligi, anak kalo, pucuak pisang, lagu duo, zapin, tanjuang katuang, piaman lamo dan lain-lain. Lagu-lagu daerah Jawa (lagu-lagu pop) seperti, anoman obong, cucak rowo, bojo loro, kencang, stasiun balapan, baling kempling, mendem wedok, jali-jali dan lain-lain. Lagu-lagu daerah Batak (lagu-lagu pop) seperti, sinanggar tullo, alusia, anak konki do hasangapon, otona batak dan lain-lain. Terkait dengan itu Titin (penyanyi gamat) mengungkapkan,

"awal munculnya bermacam lagu dinyanyikan saat penampilan acara-acara pesta adalah atas permintaan penonton yang hadir minta lagu Jawa, lagu Batak, bahkan lagu-lagu dangdut sekalipun, selain lagu-lagu gamat tradisi yang dinyanyikan”.

Pemaparan tersebut menunjukkan, bahwa lagu-lagu yang dinyanyikan pada pertunjukannya sesuai dengan selera konsumen, yang tentunya merupakan suatu kesenangan dan kenyamanan bagi penikmat. Sehubungan dengan itu Sumaryo (1978: 9) menjelaskan musik terwujud atas unsurunsur antara lain adanya kelompok manusia pencipta (komponis), adanya manusia penyaji (musisi/seniman pelaku), dan kelompok manusia penikmat (penonton). Ketiga unsur tersebut terdapat pada musik gamat. Unsur pencipta pada umumnya dalam lagu-lagu gamat tradisional tidaklah ditonjolkan (anonim). Hal itu secara etika tradisional Minangkabau mencerminkan bahwa sikap kebersamaan dalam musik gamat masih dipertahankan, walaupun juga sudah diselingi lagulagu ciptaan Jawa dan Batak (lagu-lagu cipaan dari daerah lain).

Secara garis besar tata sajian musik gamat dapat dibagi atas dua aspek yaitu aspek musikal dan aspek nonmusikal. Yang berhubungan dengan aspek musikal terkait langsung dengan anggota musisinya yang berperan sebagai pelaku musik secara teknis. Beberapa peran musisi yang diganti adalah pemain biola, keyboard (ganti acordion), gitar (pembawa melodi, rytem dan harmoni), saron, cuk (pembawa harmoni), gandang dol, ketipung dan set drum (pembawa ritmis), dan penyanyi (pembawa lirik lagu). Kesemua peran itu saling berhubungan satu sama lain dalam mewujudkan musik yang harmonis.

Dalam kaitan unsur kelompok manusia penikmat seni, musik gamat terutama digunakan sebagai hiburan atau tontonan masyarakat. Pertunjukan ini tadinya hanya disajikan dalam rumah, biasanya malam hari dari pukul 20.00 WIB sampai pukul 04.00 WIB dan juga sebelumnya dipertunjukan hanya sebagai tradisi pesta perkawinan masyarakat Minangkabau. Namun saat ini terdapat pula dalam acara pesta perkawinan yang berfungsi mengarak pengantin laki-laki ke rumah pengantin perempuan di masyarakat Jawa selain di masyarakat Minangkabau . Di samping itu juga musik gamat disajikan pada acara-acara hiburan lainnya. Seperti dikatakan Adjoem,

"musik gamat sering dipentaskan sebagai hiburan masyarakat luas bahkan dari berbagai kalangan masyarakat di Sawahlunto, baik acara pesta dalam masyarakat Minangkabau, Jawa dan Batak antara lain berupa memeriahkan pesta perkawinan, khitanan, syukuran, ulang tahun dan pada hari-hari besar nasional dan even-even nasional lainnya di luar kota Sawahlunto"

Dari realitas struktur, instrumen maupun lagulagu musik gamat tersebut di atas sesungguhnya telah terjadi pembongkaran dari ketradisian musik gamat, sehingga mewujudkan musik gamat dalam 
bentuk lain (baru) di masyarakat. Hal itu sesuai dengan yang dikemukakan Ratna (2006: 161, 221) bahwa salah satu ciri khas postrukturalisme adalah dekonstruksi, strukturalisasi sekaligus menyempurnakan terhadap sifat-sifat laten strukturalisme. Eskspresi berbagai budaya dapat dilihat melalui struktur yang dibangun oleh karya musik. Pelaku seni dalam pertunjukan musik gamat merupakan perpaduan unsur berbagai budaya (Minangkabau, Batak, Jawa modern). Salah satu contoh musik gamat dari aspek garap struktur musikal, terlihat dalam bentuk partitur musik Lagu Duo.

\section{Lagu Duo}

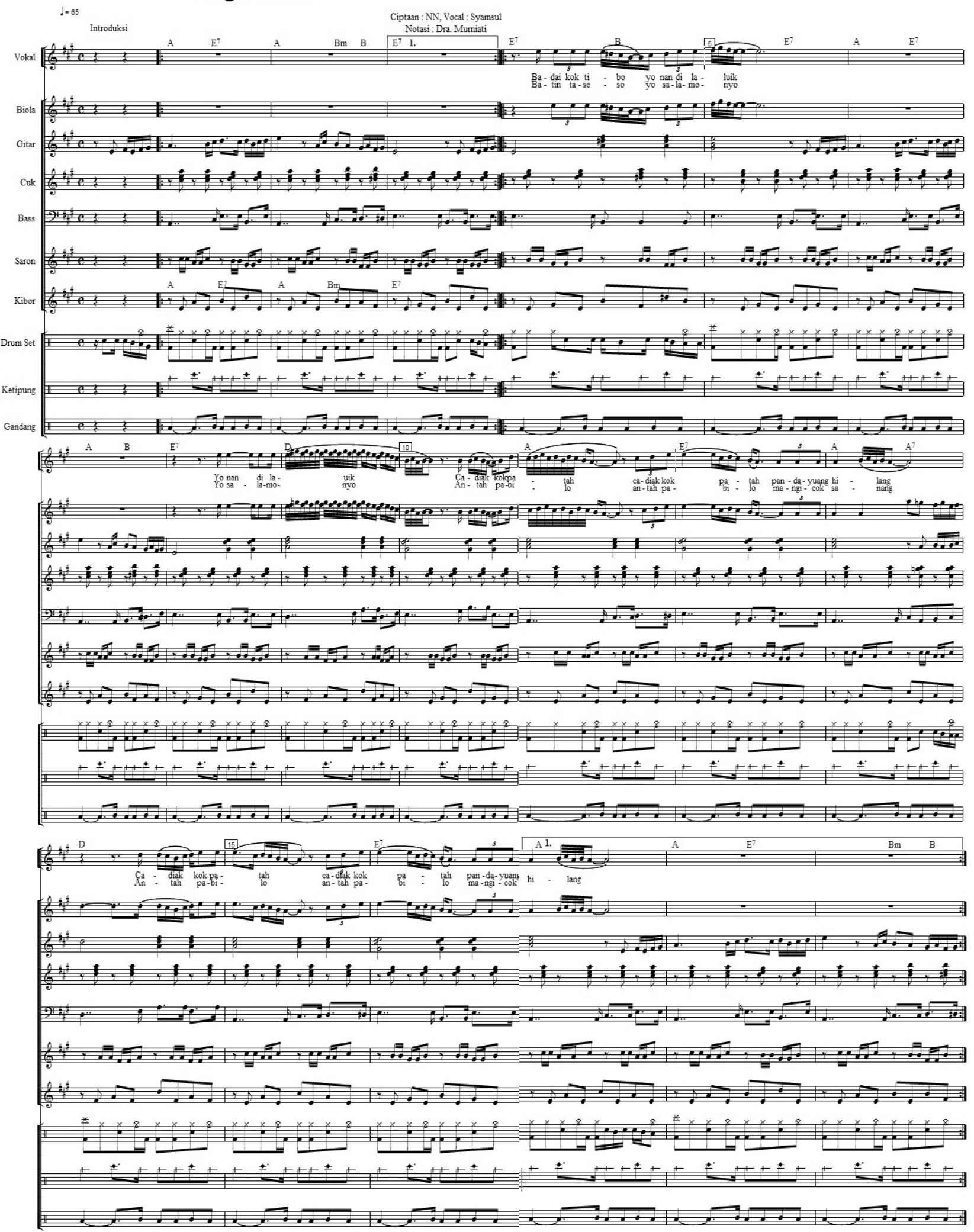




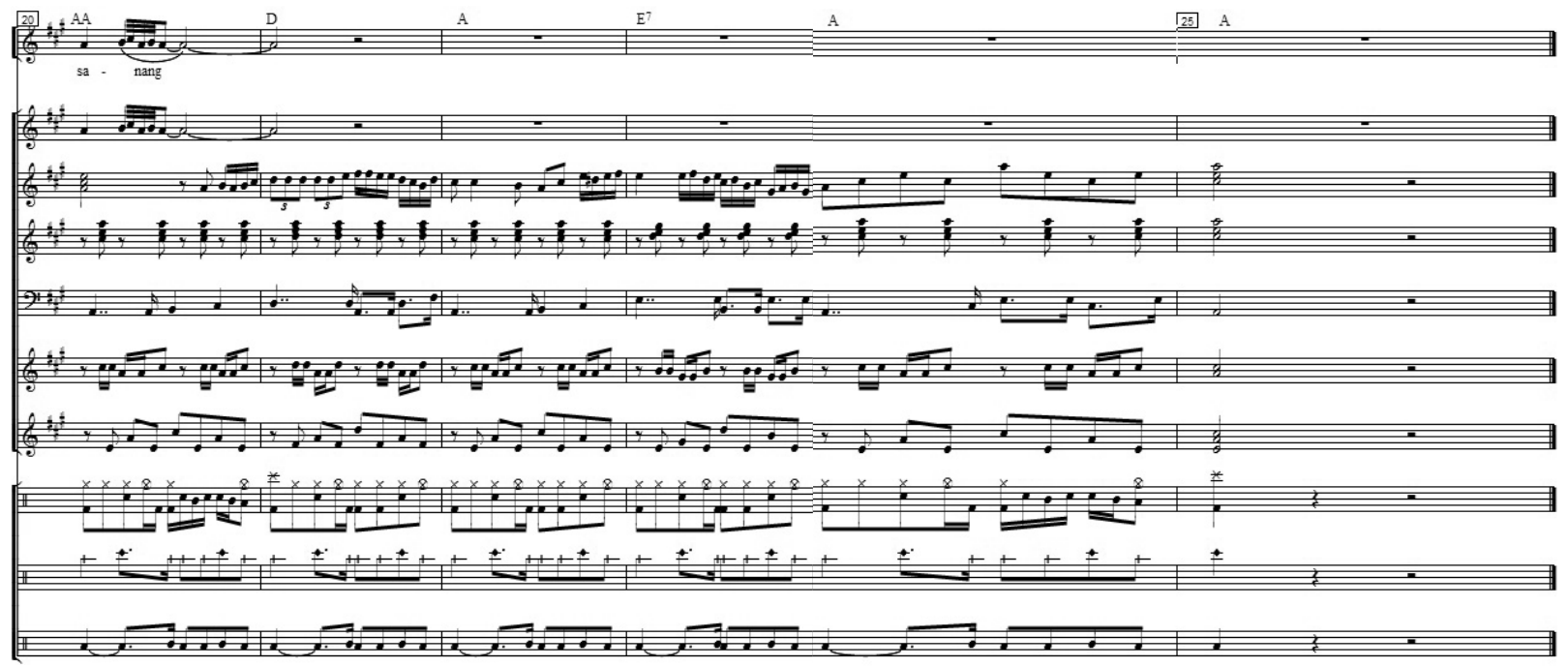

Dari score partitur terlihat adanya perpaduan unsur vokal dan idiom instrumen musikal mewujudkan kesatuan dari keanekaragaman estetis musikal dalam memainkan "lagu duo" musik gamat.

\section{Makna Musik Gamat}

Makna adalah sesuatu yang sangat sentral di dalam dunia objek. Berhubungan dengan sebuah objek tidak hanya sekedar menggunakan nilai guna, atau fungsi utilitasnya, namun ingin mengkaitkan objek tersebut dengan nilai tanda serta maknamakna tertentu, terutama kaitannya dengan makna kehidupan. Terkait hal itu, setiap pertemuan dan pertukaran budaya, akan menggiring pada proses 'reposisi' makna, nilai dan identitas budaya, tanpa harus mengorbankan nilai-nilai dasar budaya lokal itu sendiri, sehingga hal tersebut dapat dikembangkan secara kreatif ekspresi kultural dan dapat saja muncul makna baru, kaya dan kompleks (Piliang, 2005: 6-7).

Dekonstruksi makna musik gamat dalam masyarakat Sawahlunto dapat dilihat dalam makna ekspresi, kreativitas, estetis multikultural, dan pembauran. Musik gamat Sawahlunto, dengan hadirnya diberbagai bentuk hiburan di masyarakat merupakan masalah sosial yang ditemukan di masyarakat. Musik gamat secara sosial bukan hanya dipandang sebagai kelahiran kembali genre musik baru akan tetapi eksklusivitasnya dibidang tema lirik, musikalisasi serta penampilan para musisinya juga di tengarai sebagai titik awal terjadinya pemberontakan terhadap nilai-nilai sosial yang sudah mapan, di samping pemberontakan terhadap kemapanan dalam bermusik. Terkait dengan masalah ini, Adjoem, seorang musisi gamat mengungkapkan:

"melalui kegiatan seni yang terbentuk pada kelompok ini kami antara musisi terjalin kebersamaan, kekeluargaan walau kami berbeda etnis, saling memahami dan menghargai perbedaan untuk menyajikan yang terbaik di masyarakat".

Dengan demikian, kesenian sebagai medan ekspresi sosial dan kesadaran yang paling inti dari salah satu budaya atau dari beberapa budaya di antaranya dapat dilihat pada bentuk tema (syair lagu). Pantun-pantun yang didendangkan dalam kelompok musik gamat merupakan wahana ekspresi emosi bagi penyanyi dalam mengungkapkan peristiwa-peristiwa kehidupan sosial. Tema lirik yang digunakan dalam pertunjukan gamat cenderung beragam yaitu tiga unsur budaya/lagu Minangkabau, Jawa, dan Batak.

Musik gamat sebagai karya seni juga merupakan pantulan realitas. Bentuk atau model karya seni atau apapun sesuai intensi dan andalan sikap penciptanya. Begitu juga sikap yang dihadapi para musisi gamat yang terlihat kebersamaan antar etnis yang beragam baik aktivitas saat latihan maupun saat pertujukan dan juga dari model sajian karya penggunaan instrumen dan lagu-lagu yang disajikan dalam kesatuan. Selain itu ekspresi estetika dapat dilihat pada pengaplikasian terhadap karyakarya seni itu baik ketika diciptakan (kreativitas) 
maupun ketika diserap dan dinikmati (apresiasi seni), Berbeda dengan wacana estetika yang cenderung merupakan sistem tertutup, terdapat apa yang disebut sebagai "nilai seni", dalam arti bagaimana orang melihat karya seni atau kegiatan berkesenian dalam kerangka fungsi-fungsi sosial (Sedyawati, 2006: 365). Dalam suatu karya seni sebagai suatu karya manusia akan dapat banyak dijumpai suatu kreativitas seni. Hal tersebut juga dijumpai pada musisi gamat. Seorang musisi masa dahulu atau sekarang mestilah selalu memiliki suatu kreativitas yang tinggi. Dengan demikian, munculnya musik gamat dalam bentuk baru seirama dengan apa yang dikemukakan Warsana (2012: 76-77) bahwa lahirnya sebuah karya musik adalah sebagai perwujudan atau manifestasi diri yang dilatarbelakangi oleh pengalaman pribadi maupun lingkungan yang mempengaruhinya

Kegiatan seni merupakan ajang untuk peningkatan kreativitas dan apresiasi seni masyarakat, tanpa terkecuali makna serupa juga terdapat pada musik gamat, seperti pengakuan pelaku seni Hermanto, "melalui kegiatan musik gamat ini, baik saat latihan maupun saat pertunjukan kami dapat belajar banyak tentang musik gamat untuk lebih meningkatkan wawasan seni dalam bermasyarakat”.

Kreativitas yang dilakukan oleh kelompok/ musisi gamat terletak pada proses latihan, baik dalam pemanfaatan variasi instrumen maupun alternatif kebebasan struktur sajian lagu-lagu, sehingga sentuhan-sentuhan garapan (interpretasi estetis) memberikan nuansa berbeda pada setiap sajian yang telah berubah. Dari suatu sisi, estetika adalah studi seni dan keindahan yang berkaitan erat dengan pengalaman estetik. Pengalaman seni sebagai proses pembudayaan tersebut dimiliki seniman pelaku antara lain Adjoem (pemain biola dan saron) sekaligus sebagai pimpinan kelompok musik gamat. Senada dengan yang dijelaskan Sachari (2002:104) pemberontakan dan kreativitas adalah dua hal yang memiliki keterkaitan. Sebagian besar tindakan kreatif umumnya merupakan suatu bentuk pemberontakan terhadap tatanan lama. Demikian juga sebaliknya, dalam pemberontakan terkandung pula usaha-usaha kreatif. Keduanya merupakan perjuangan untuk membebaskan diri dari batasan tatanan yang ada dan dianggap usang dengan mencari alternatif-alternatif baru yang lebih sesuai dengan kebutuhan.

Garapan-garapan karya seni yang dilakukan oleh para musisi akan meningkatkan kreativitas pada penggabungan instrumen dan unsur-unsur lagu yang dibawakan dari berbagai lagu tradisi etnis. Pada awalnya beberapa lagu muncul karena permintaan para penonton, tapi akhirnya menjadi suatu hal yang sangat menarik, hingga menjadi suatu yang membudaya dan menjadi ciri dari musik gamat kekinian. Kelebihan dari para penyanyi dan musisi dalam pertunjukan gamat adalah dimana mereka dapat membawakan lagu-lagu dari berbagai daerah lain di Nusantara dan menjadikannya sebagai bentuk lagu dalam budayanya. Di samping itu kreativitas pelaku juga bisa terlihat dari cara memanfaatkan instrumen Barat seperti keyboard dan instrumen elektronik lainnya yang dilatih secara manual. Ini dilakukan untuk mengantisipasi musik yang sudah diprogram melalui komputer, karena hal itu menurut anggota musisi tersebut akan menurunkan kreativitas bermain musik secara manual serta kemampuan individual.

Representasi musik gamat menghasilkan beraneka ragam kecenderungan makna, sehingga memerlukan interpretasi dalam memahaminya. Segala bentuk idiom dari elemen-elemen instrumen (tradisi dan modern), pakem, bentuk struktur sajian lagu dari berbagai budaya (bahasa teks lagu, busana dan gaya teknik sajian) di masyarakat secara modern, termasuk properti yang digunakan dan lain-lain membangun persatuan dan kesatuan dalam seni musik gamat. Keterpaduan dalam sebuah sistem seni akan memberikan rasa estetis bagi penyaji dan penikmat.

Eksistensi seni merupakan suatu usaha untuk menciptakan bentuk simbol yang menyenangkan, tidak mengungkap pada taraf keindahan saja namun juga mengandung maksud yang baik bersifat pribadi maupun sosial (Sumandyo, 2005: 34). Terkait dengan itu, multikulturalisme adalah sebuah filosofi yang berarti berbagi dan membentuk bersama-sama. Objektivitas umum harus merupakan sebuah keinginan dan pertanggungjawaban terhadap bagian dari setiap kelompok untuk mengerti dan menghargai 
kontribusi orang lain tehadap kemampuan umum. Seperti telah disinggung terdahulu, hal itu terlihat dari pluralitas alat musik dan pluralitas musikal yang digunakan dalam musik gamat.

Dari aneka pencampuran simbol, secara teknis terlihat pada instrumen saron (jawa) membawakan nada-nada harmonis dalam diatonis dengan tehnik memainkan talempong (instrumen Minangkabau) menggunakan dua alat pemukul saling mengisi (arpeggio) dan tidak dengan teknis tradisi memainkan saron dengan satu alat pemukul dan di patet, baik dalam membawakan teks lagu-lagu berbahasa Minangkabau, bahasa Jawa, maupun lagu-lagu berbahasa Batak. Dengan demikian sangat terlihat kode-kode ganda dalam menghasilkan kode-kode baru yang tampak dalam aneka pencampuran simbol dan sebagainya. $\mathrm{Hal}$ itu merupakan hasil dari kreativitas seniman pelaku yang berbeda-beda memiliki tujuan dan perlu penafsiran penikmatnya, dan sekaligus berupa bentuk ekspresi yang disampaikan dalam bentuk tanda atau simbol sehingga terkandung estetika multikultural.

Berhubungan dengan ini dikemukakan Piliang (2006: 8) berbagai kemungkinan baru estetis, baik kecendrungan baru seni sastra sebagai akibat dari berbagai peluang antara lain; dialog, translasi, pertukaran, negosiasi, dan transposisi. Dalam hal ini sebagai konsekuensi dari perlawanannya terhadap universalisme, sentralisme dan homogenisasi kultural, baik pluralisme maupun multikulturalisme menawarkan perbedaan dan keanekaragaman sebagai prinsip dasarnya, yang menghasilkan beranekaragam kecenderungan (estetik, idiom dan gaya) di antaranya yaitu multikulturalisme kritis, multikulturalisme intertekstual, multikulturalisme hibrid, dan multikulturalisme eklektik.

Multikulturalisme kritis, berupa upaya-upaya perjuangan kultural dan estetik ke arah eksistensi, persamaan hak, emansipasi, politik representasi dan politik posisi. Dalam estetika multikultural dibangun semacam ruang kritik atau ruang subversi, yaitu ruang untuk mempertanyakan, membongkar atau mempermainkan posisi estetik atau kultural hegemonik dari sebuah budaya dominan, dengan berbagai idiom atau ironi. Multikultural interteks, membuka ruang bagi berbagai 'pelintasan estetik' dan pelintasan yang mempertemukan dua atau lebih teks, dua waktu, dua ruang, dan dua konteks yang berbeda. Piliang (2006: 8) menyebut kecenderungan semacam ini sebagai intertekstualitas (sebuah ruang pelintasan tekstual) yang di dalamnya berbagai ungkapan dan teks-teks saling bertemu, berdialog dan bersilangan. Multikultural Hibrid, merupakan perkawinan silang di antara berbagai bentuk budaya menghasilkan bentuk hibrid estetik. Hibridasi adalah proses penciptaan bentuk-bentuk 'mutan' melalui perkawinan silang estetik, yang menghasilkan bentuk-bentuk 'blesteran'. Hibridasi dilihat dari bentuk kode ganda, yaitu percampuran dua kode yang berbeda untuk menghasilkan kode baru mungkin berupa bentuk, gaya, ideologi, tanda, makna, bahkan konsep, dan misalnya tampak dalam aneka percampuran simbol. Multikulturalisme eklektik, yang merupakan prinsip mencomot dan menggabungkan berbagai bentuk, bahkan bertentangan tanpa ruang kritik dalam rangka menciptakan sebuah kombinasi yang berbeda, seperti adanya pengkombinasian antara seni modern dengan seni tradisi.

Dari uraian di atas, pada musik gamat terkandung makna estetika multikultural hibrid dan multikultural eklektik. Dari sisi pandangan multikultural hibrid, dunia musik gamat dibangun berdasarkan prinsip pencampuran pada tingkat bentuk, estetik, idiom dan gaya dari bermacam unsur budaya etnis dan unsur budaya teknologi modern. Dari sisi pandangan multikultural ekletik, dunia musik gamat sekarang terlihat pada bentuk sajian lagu-lagu, yang secara tradisi khusus membawakan struktur lagu-lagu gamat (joged dan langgam), namun sekarang sudah bercampur baur gaya struktur sajiannya dengan memasukkan atau mencomot unsur lagu-lagu daerah Jawa dan lagulagu daerah Batak, bahkan lagu-lagu daerah lain, lagu-lagu pop barat, dan ini tidak terlepas dari peran serta instrumen modern.

Dengan demikian eklektisisme tidak lagi mengikat diri pada sebuah kepastian gamat, sehingga membiarkan kecairan identitas dengan bertemunya aneka bentuk, prinsip, tanda, simbol, idiom dan nilai-nilai, bahkan yang saling bertentangan sekalipun. Berarti ekletisisme membiarkan identitas 
dalam keadaan tidak konsisten (inkonsistensi), ketidaktepatan dan ketidakpastian. Di sisi lain, kepribadian dalam kebudayaan untuk memahami identitas budaya bangsa adanya kebudayaan etnik yang beraneka ragam membangun kebudayaan baru yang memperkaya kebudayaan tradisi, berkepribadian nasional yang kuat yang berarti penghargaan dan pemahaman masyarakat secara lintas budaya etnik.

\section{Penutup}

Berdasarkan uraian di atas dapat disimpulkan bahwa dekonstruksi musik gamat merupakan pergeseran bentuk yang nampak dari struktur organisasi masyarakat pelaku seni yang heterogen, aspek bentuk dan struktur sajian, estetika musik gamat, serta konteks dan waktu pertunjukan di masyarakat. Semuanya telah mengalami pembongkaran dari ketradisian musik gamat memunculkan suatu bentuk dan nilai baru yang mempunyai arti tersendiri bagi masyarakat seniman pelaku, penikmat maupun masyarakat luas dari beragam etnis dan budaya yang mewujudkan praktek-praktek budaya/seni sebagai karya masyarakat menjadi wujud kesatuan.

Representasi musik gamat secara umum mengandung makna pembauran, ekspresi sosial, kreativitas pelaku dan ekspresi sajian serta estetika multikultural. Makna estetis menunjukkan musik gamat dapat memberikan hiburan estetis, mengandung kreativitas dan apresiasi serta komunikatif seni dari seniman pelaku kepada masyarakat penikmatnya. Makna estetika multikultural menunjukkan musik gamat adalah sebuah bentuk akulturasi budaya yang mengandung estetika multikultural bersifat hibridasi dan eklektik.

Makna ekspresi sosial pada musik gamat mengekspresikan sikap rasa kebersamaan antar etnis berbagai budaya sesuai dengan konteks dimana musik diekspresikan dalam menghargai sifat kreativitas dari rasa kesukubangsaan melalui pengekspresian materi yang disajikan pada masyarakat maupun aktivitas dalam berkesenian. Musik gamat menunjukkan karya musik yang bersifat kolektif membangun sosial masyarakat untuk saling menghormati keberagaman dan menghargai perbedaan. Musik gamat mengandung makna pembauran dalam wujud kesatuan merupakan identitas budaya bangsa 'Bhinneka Tunggal Ika', karena memiliki sikap pemahaman, penghargaan, serta penghormatan antar budaya etnis yang berbeda dalam wujud kesatuan dengan mengambil nilai-nilai yang ada di masyarakat.

\section{Kepustakaan}

Barker, Chris. 2005. Cultural Studies Teori dan Praktek., Yogyakarta: PT Benteng Pustaka.

Dharsono (Soni Kartika). 2007. Estetika. Bandung: Rekayasa Sains

Hadi, Sumandyo. 2005. Seni Dalam Ritual Agama. Yogyakarta: Pustaka.

Hendry, Yon. 2011. "Musik Keroncong Campur Sari Dalam Pluralitas Budaya Masyarakat Sawahlunto" dalam RESITAL: JURNAL SENI PERTUNJUKAN, Volume 12 No. 1- Juni 2011: 84- 95.

Lubis, Akhyar Yusuf. 2004. Masih Adakah Tempat Berpijak Bagi Ilmuan. Bogor: Akademia.

L. E, Sumaryo. 1978. Komponis, Pemain Musik dan Publik. Jakarta: Pustaka Jaya.

Md. Nur, Muhd. Anis. 2000. "Dari Tradisi ke Tradisi, Transformasi Seni Pertunjukan di Asia Tenggara " dalam Jurnal SPI tahun 2000.

Murniati. 2007 "Musik Gamat Pencerninan Multikultural di Kota Sawahlunto Provinsi Sumatera Barat”. [Tesis S2] Program Studi Kajian Budaya, Program Pascasarjana Universitas Udayana Denpasar.

Norris, Christopher. 2003. Membongkar Teori Dekonstruksi Jacques Derrida. Yogyakarta: Ar-Ruzz.

Piliang, Yasraf Amir. 2006. “"'Sastra Plural atau Multikultural": Menafsir Ulang Perbedaan dan Keanekaragaman" [Makalah] Seminar Temu Sastra II MPU di Sanur, Bali. ,2005. "Menciptakan Keunggulan Lokal Untuk Merebut Peluang Global: Sebuah Pendekatan Kultural" [Makalah] Seminar Nasional di ISI Denpasar, 26 Juli 2005.

Ratna. I Nyoman Kutha. 2007. Sastra dan Cultural Studies: Representasi Fiksi dan Fakta. Yogyakarta: Pustaka Pelajar. 
2006. Teori, Metode dan Teknik Sastras. Yogyakarta: Pustaka Pelajar.

Ritzer, George. 2003. Teori Sosial Postmodern. Yogyakarta: Kreasi Wacana

Sachari, Agus. 2002. Estetika: Makna, Simbol dan Daya. Bandung: ITB

Sedyawati, Edi. 2006. Budaya Indonesia: Kajian Arkeologi, Seni, dan Sejarah. Jakarta: PT Raja Grafindo Persada.

Spivak, Gayatri, 2003. Membaca Pemikiran Derrida: Sebuah Pengantar. Yogyakarta: Arruz.

Soedarso, Sp. 1990. Tinjauan Seni. Yogyakarta: Suku Dayar Sana.

Sumardjo, Jacob, 2000. Filsafat Seni. Bandung: Penerbit ITB.

Warsana. 2012. “Tumpang Tindih: Sebuah Komposisi Musik Dalam Interpretasi Personal" dalam RESITAL: JURNAL SENI
PERTUNJUKAN, Volume 13 No. 1- Juni 2012: 74- 94.

\section{Informan}

Adjoem (72 tahun), ketua kelompok musik gamat dan seniman musik keroncong campursari di Sawahlunto.

Z. Arifin (66 tahun), pemain biola dan musisi gamat tradisional di Sawahlunto.

Hermanto (52 tahun), musisi instrumen keyboard di Sawahlunto.

Srimujihartini (36 tahun), penyanyi gamat dan musik campursari di Sawahlunto.

Syamsul (50 tahun), penyanyi gamat tradisional di Sawahlunto.

Marlinus (55 tahun), pemain saron dan penyanyi gamat di Sawahlunto. 